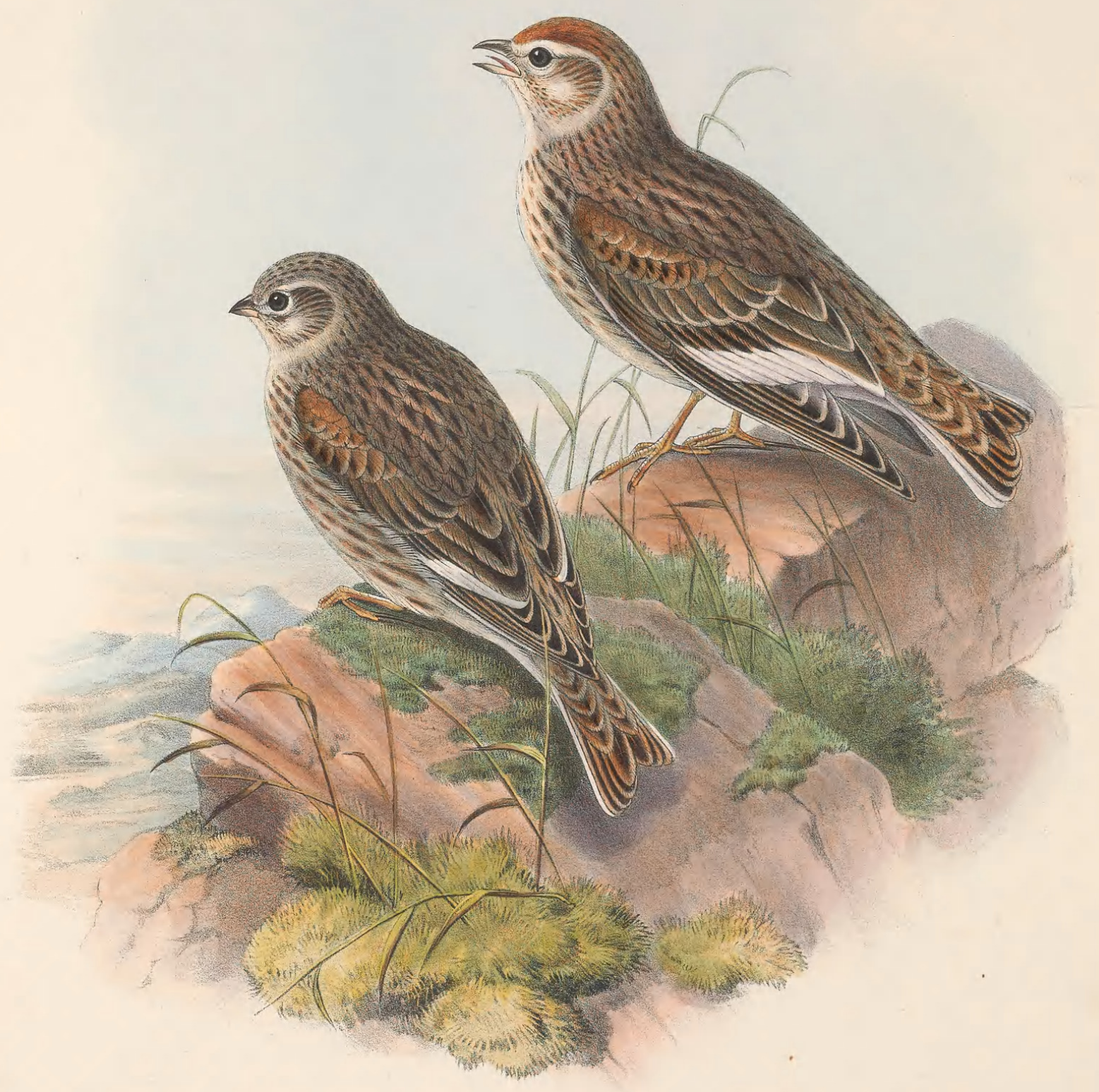




\title{
MELANOCORYPHA LEUCOP'TERA.
}

\author{
White-winged Lark.
}

Alauda leucoptera, Pall. Zoog. Rosso-Asiat., tom. i. p. 518, tab. 33. fig. 2.

sibirica, Gmel. edit. Linn. Syst. Nat., tom. i. p. 799.

bimaculata?, Ménétr.

Calandrella sibirica, Brandt.

Phileremos sibirica, Keys. et Blas. Wirbelth. Eur., p. 37.

leucoptera, Blas. List of Birds of Eur., Newton's Eng. edit. p. 12

Melanocorypha leucoptera, Bonap. Consp. Gen. Av. tom. i. p. 243, Melanocorypha, sp. 5.

A FINE specimen of this eastern bird was captured near Brighton in the latter part of the year 1869, prior to which the furthest westward that the species was known to have occurred is the environs of Liége ; where, M. Ch. F. Dubois states in his 'Oiseaux de la Belgique,' an example, in the possession of the Baron de Selys-Longchamps, was taken in December 1855. Captain Blakiston obtained examples in the Crimea; $\mathrm{Mr}$. Tristram has others from the Volga ; and the earlier writers describe it as inhabiting Siberia ; it is, in fact, another of the many Continental birds that have of late years wandered into the British Islands, such as the Sand-Grouse, Scindian Bustard, and others.

The White-winged Lark is a fine species, and, if it occurred frequently with us, would add considerably to the interest of our avifauna. By Pallas and Latham it was regarded as a variety of the Calandra Lark; but although nearly allied to, it is really quite distinct from that species. Its proper home seems to be Siberia, Tartary, and Southern Russia; but it occasionally occurs in Poland, and, as above mentioned, Captain Blakiston found it in the Crimea. Of its habits, manners, and general economy but little is known; that little I shall here give on the authority of the various writers.

Latham says, "this is plentiful in the sumny fields, in the neighbourhood of the river Irtish, in Siberia, where it makes its nest on the ground, like the Skylark, but is inferior to it in song."

Dubois remarks that " its voice is not so agreeable as that of the Skylark; but its movements are equally elegant. It nests like it on the ground in a slight excavation. It is not very timid, and allows people to approach closely without fear."

Speaking of the bird in the Crimea, Captain Blakiston says, in the 'Zoologist' for 1857, p. 5509 :-

"A few days after this, the 5th of January, I was again on the qui vive, as a friend told me he had seen some Buntings, white below and rusty-colour above; with this hint I made for a camp where he said some had been shot, the ground being covered with snow; and sure enough, on looking over a heap of small birds, I found the Calandra Lark, Common Bunting, and another new to me, which I put down for distinction, as a 'Lark Bunting, No. 20,' the skin as well as the sternum of which I preserved. The same officer, a day or two after, kindly sent me a specimen of the same bird, the White-winged Lark (Alauda leucoptera), a male. I never observed or heard of this species again; on my return to England Mr. Gould kindly made this bird out for me."

Of the occurrence of the bird in England, all that has been recorded is comprised in the following brief notices, published by Mr. Bond in the 'Zoologist' for 1870. At page 1984, after enumerating a number of rare or new British birds which had been taken near Brighton between September and the 6th of December, 1869, he says :- "I also saw another bird, which I believe to be a young Snowfinch (Fringilla nivalis). I saw it very shortly after its capture, and am quite sure of its being a truly wild bird. I hope soon to send you more particulars." Accordingly at page 2022 he says :- "The bird I believed might be a young Snowfinch is a specimen of the Siberian Lark, the first that has been recorded as occurring in Britain, and a very interesting addition to our list, as it is very rare as a European species." To this the Editor adds:- “Mr. G. Dawson Rowley has favoured me with a note to exactly the same purport, and adds that Professor Newton acquiesces in this decision."

The sexes differ considerably; the rufous colouring of the crown of the male, and the greater amount of white across his wings, render him by far the finest bird of the two. The plumage of the example taken near Brighton, which is now, I believe, in the possession of T. J. Monk, Esq., of Mountfield House, Lewes, is represented by the lower figure in the accompanying Plate.

The male has the head, shoulders, and the base of the tail rufous; the upper surface of the body greyish brown, with a blackish-brown stripe down the centre of each feather; wings dark brown, the external feather margined with white, the remainder tipped with light reddish brown; secondaries 
largely tipped with white, forming a conspicuous band; outer tail-feather on each side white, the remainder dark brown, narrowly edged on both margins with white, and slightly tipped with rufous; central feathers brown, broadly margined with rufous; ear-coverts striated with brown and russet red; under surface white, with numerous small striæ from the angle of the mouth; a series of brown and russet-coloured spots across the breast; and a series of rufous and brown striæ on the sides and flanks; bill dark brown, except at the base of the under mandible, where it is creamy white; legs, toes, and claws brown.

The female is very similar, but has no rufous on the head, less white across the wings, the markings less decided, and is generally of a darker hue.

The Plate represents the two sexes, of the size of life. 


\section{$2 \mathrm{BHL}$ Biodiversity Heritage Library}

Gould, John. 1873. "White-winged Lark, Melanocorypha leucoptera [PI. 20]." The birds of Great Britain 3, -. https://doi.org/10.5962/p.323911.

View This Item Online: https://www.biodiversitylibrary.org/item/221726

DOI: https://doi.org/10.5962/p.323911

Permalink: https://www.biodiversitylibrary.org/partpdf/323911

\section{Holding Institution}

Smithsonian Libraries

\section{Sponsored by}

Biodiversity Heritage Library

\section{Copyright \& Reuse}

Copyright Status: Public domain. The BHL considers that this work is no longer under copyright protection.

This document was created from content at the Biodiversity Heritage Library, the world's largest open access digital library for biodiversity literature and archives. Visit BHL at https://www.biodiversitylibrary.org. 